\title{
Bybelstudie vir studente en jongmense om tot 'n lewende verhouding met God te groei
}

\begin{abstract}
Book Title:
Dink aan jou Skepper in jou jongdae

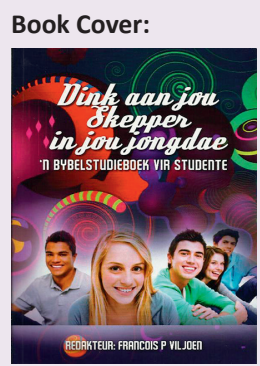

Author:

Viljoen, F.P. (eds.)

ISBN:

978-0-86955-218-6

Publisher:

Na die lees van die voorwoord besef 'n mens al dat hierdie boek nie maar net nog 'n gewone Bybelstudieboek is nie. Francois Viljoen, die redakteur, skryf in die voorwoord dat studente dit soms moeilik vind om Bybelstudie te doen en dat hulle nie altyd weet hoe om 'n Bybelstudie aan te pak nie. Dink aan jou Skepper in jou jongdae is 'n boek wat waarlik op jongmense en hulle behoeftes gerig is.

Die boek word in vyf dele of hooftemas verdeel, naamlik Ek gaan studeer; My verhouding met God; My ander verhoudings; Vrae wat pla; en Gemoedstoestande waarmee ek te doen kry.

Die hoofstukke is volgens studente se behoeftes ingedeel. Die eerste hoofstuk handel oor die student wat nuut is op kampus. Die studente bevind hulself in 'n nuwe omgewing en met nuwe uitdagings. Hulle moet toegerus word om die verskillende uitdagings te kan hanteer, daaruit te leer en in hulle verhouding met God te groei. Hierdie uitdagings kan in die vorm van eksamens en toetse wees, die bestuur van persoonlike finansies, leierskap in die studentegemeenskap en die keuses wat studente moet maak nadat hulle hulle graad voltooi het. Elke student gaan uitdagings ervaar en daarom is dit belangrik om 'n Bybelstudieboek te hê wat studente na die waarheid en 'n lewende verhouding met God kan lei - te midde van die uitdagings wat aan hulle gestel word.
\end{abstract}

Potchefstroom Theological Publications, 2014, R125.00* *Book price at time of review

Review Title:

Bybelstudie vir studente en jongmense om tot' $n$ lewende verhouding met God te groei

\section{Reviewer:}

Ruan Steyn ${ }^{1}$

\section{Affiliation:}

${ }^{1}$ Faculty of Theology,

North-West University,

Potchefstroom Campus,

South Africa

Email:

steyn.ruan1@gmail.com

\section{Postal address:}

Silwerwoods 25, Silver

Street, Potchefstroom 2520,

South Africa

Read online:

Scan this QR

code with your

smart phone or

mobile device

to read online.

Die tweede hoofstuk handel oor die jongmens se verhouding met die Here. My persoonlike siening is om eerste met hierdie hoofstuk te begin, voordat ek die ander hoofstukke wil lees. Die rede hiervoor is dat die jongmens in hierdie tweede hoofstuk geleer word om 'n Bybelstudie te doen. Dit is egter belangrik om eers na jou verhouding met God te kyk voordat jy met die ander temas kan aangaan. Die grootste gebod is om God lief te hê. Dit is van groot belang om hierdie konsep eers te verstaan, voordat 'n mens kan leer om ander mense en jouself lief te hê. Dit is egter ook belangrik om te weet hoe om 'n Bybelstudie aan te pak om waarlik ten volle die boodskap te verstaan, sodat geloofsgroei kan plaasvind.

Nadat jongmense (studente) Bybelstudie oor hulle verhouding met God gedoen het, doen hulle Bybelstudie oor hulle verhouding met ander mense. Hierdie hoofstuk is belangrik aangesien studente die grootmenswêreld betree. Dit beteken dat hulle met verskillende mense uit verskillende dorpe en met verskillende ideologieë te doen gaan kry. Die kans is ook groot dat studente hulle lewensmaat op universiteit gaan ontmoet. Daarom is dit noodsaaklik om uit die Skrif te leer hoe ' $n$ mens met ander mense moet saamleef. Studente moet ' $n$ besef van ware liefde ontwikkel. Indien 'n mens bely dat God liefde is, moet ons ook ons naaste liefhê.

Deel vier bestaan uit onderwerpe waaroor studente gewoonlik vrae het. Hierdie hoofstuk hanteer onderwerpe soos seks, drank en dwelms, aborsie, godsdiens, hoe God sekere lyding kan toelaat, die verband tussen wetenskap en godsdiens, sosiale netwerke, ensovoorts. Studente word gewoonlik met hierdie vrae en nog ander onderwerpe gebombardeer. Hulle gaan te doen kry met wêreldse dinge, byvoorbeeld seks, drank en dwelms. Hierdie Bybelstudieboek rus studente toe om die waarheid te soek sodat hulle aan hierdie verkeerde wêreldse dinge kan nee sê.

Tydens die studiejare kry studente met verskillende gemoedstoestande te make. Hoofstuk 5 hanteer die verskillende gemoedstoestande waarmee studente oor die algemeen te doen kry, byvoorbeeld depressie, kompulsiewe eetgewoontes, selfmutilasie, trauma, innerlike genesing, emosionele bagasie, beheptheid met seks en pornografie, skuld en skaamte se vergifnis.

How to cite this book review: Steyn, R., 2015, 'Bybelstudie vir studente en jongmense om tot 'n lewende verhouding met God te groei', In die Skriflig 49(1), Art. \#1965, 2 pages. http://dx.doi.org/10.4102/ids.v49i1.1965

Copyright: ( 2015 . The Authors. Licensee: AOSIS OpenJournals. This work is licensed under the Creative Commons Attribution License. 
Elke hoofstuk begin met inleidende opmerkings wat die aktualiteit van die Bybelstudie beskryf. Hierdie opmerkings is sodanig geskryf dat die lesers dadelik die tema en die aktualiteit van die Bybelstudie kan verstaan. Na die inleidende opmerkings volg die Bybelgedeeltes wat oor daardie spesifieke tema handel.

Dink aan jou Skepper in jou jongdae kom uit die pen van verskillende bekwame skrywers. Elke hoofstuk is deur iemand geskryf wat in daardie spesifieke veld spesialiseer. Die standaard van hierdie boek is dus hoog.
Enigiemand wat gaan studeer, besig is om te studeer, pastore, predikante en jeugwerkers wat met studente en jongmense werk, sal moontlik in hierdie boek belangstel. Jongmense sal definitief by die lees van hierdie boek baat vind en hierdeur toegerus word om die uitdagings van die jongmenslewe te hanteer.

Ek sal hierdie Bybelstudieboek, Dink aan jou Skepper in jou jongdae, vir enigiemand aanbeveel - dit is 'n boek wat enige persoon op sy boekrak behoort te hê. 